$\underline{\beta}=$

\title{
Health risk assessment of levels of some toxic metals and polycyclic aromatic hydrocarbons of some commercial soft drinks commonly consumed among students of Nnamdi Azikiwe university, Awka, Anambra state, Nigeria
}

\author{
Rose Ngozi Asomugha ${ }^{1 *}$, Chijoke Emmanuel Igwe ${ }^{2}$, Peace Ukamaka Nome ${ }^{2}$, Onyinye \\ Mary Uchendu ${ }^{2}$, Nwamkwere Godson ${ }^{2}$ \\ ${ }^{I}$ Toxicology Unit, Department of Pharmacology and Toxicology, Nnamdi Azikiwe University Awka, Anambra State, Nigeria \\ ${ }^{2}$ Department of chemistry, Faculty of Science, Nnamdi Azikiwe University Awka, Anambra State, Nigeria \\ *Corresponding author E-mail: Rose Ngozi Asomugha r.asomugha@unizik.edu.ng
}

\begin{abstract}
Food Safety is of growing concern globally, and more so considering the relatively high proportion of soft drinks in the beverage market worldwide, and its rate of consumption especially amongst the youths. It is essential to evaluate the levels of toxic metals and Polycyclic Aromatic Hydrocarbons (PAHs) residues of which when present in soft drinks above the permissible limits could pose serious public health risk. The aim of this present study was to assess the levels of heavy metals ( $\mathrm{Pb}, \mathrm{Hg}, \mathrm{Cd}, \mathrm{As})$ and Polycyclic aromatic Hydrocarbons(PAHs) in 16 commercial soft drinks marketed in Awka, using Atomic Absorption Spectroscopy(AAS) and Flame Ionization detector (GC-FID), respectively. The carcinogenic and non-carcinogenic risk assessment were performed using the method established by United State Environmental Protection agency(USEPA).The data obtained were compared with the permissible limit set for drinking water by United State Environmental Protection Agency(USEPA),World Health Organization (WHO),Standard Organization of Nigeria(SON) and Federal Environmental Protection Agency(FEPA). The highest mean level of $0.6116 \mathrm{mg} / \mathrm{l}$ is related to $\mathrm{Pb}$ and the lowest of $0.0028 \mathrm{mg} / \mathrm{l}$ related to $\mathrm{Hg}$. The mean levels of the metals increased in this order: $\mathrm{Hg}<\mathrm{As}<\mathrm{Cd}<\mathrm{Pb}$. For the PAHs, using Benzo(a)pyrene as the benchmark for other PAHs congeners because of its strong carcinogenic potency, is not detected in this study, and thus pose no health risk. The target hazard quotient (THQ) of $\mathrm{Hg}$ in the studied samples is less than 1. Pb levels in75\% the studied samples had THQ>1, and thus, pose a health risk. The hazard index, calculated as the combined risk of heavy metal toxicity is greater than unity (HI>1).The incremental lifetime cancer risk (ILCR) values estimated for $\mathrm{Pb}$, As and $\mathrm{Cd}$ in the sample were 6.25\%,31.25\% and 25\% ,respectively, representing higher than acceptable risk value of (10-6 -10-4). The results raise a concern for the public exposed with respect to As and Cd carcinogenic risk values.
\end{abstract}

Keywords: Heavy Metals; PAHs; Risk Assessment; Soft Drink.

\section{Introduction}

Metals are widely found in our environment and food sources either naturally, or as a result of human activities such as agricultural practices, Industrial emissions or contamination during manufacture. A key potential source of exposure of metals is processed beverages that are known to contain metals (Magomya et al., 2015).Controlling the amount of heavy metals in commercial soft drink (non-alcoholic beer),cola, juice drink, and energy drink is very essential for consumer safety(Harnack et al.,1999).The accumulation of $\mathrm{Pb}$ and $\mathrm{Cd}$ in the human body can lead to cancer, kidney disorders, skeletal damage, brain damage ,reproductive failure and poisoning. In addition, one of the most toxic metal exposed to human, $\mathrm{Hg}$, is even more toxic than $\mathrm{Pb}$ and $\mathrm{As}$ and also has teratogenic and neurological effects(Fu et al.,2008). Long term exposure to $\mathrm{Hg}$, even in minute quantities, may increase the risk of skin ,lung , urinary, bladder and kidney cancer (Fang et al.,2010).

Evaluating commercial soft drinks is important for consumer safety because they are vastly consumed worldwide (Dehelean and Magdas, 2013). Soft drinks are non-alcoholic water-based flavored drinks that are optionally sweetened, acidulated and carbonated. They include all beverages which complied with the above definition, and which do not claim to be part of adjacent categories such as fruit juice and nectars, dairy drinks, mineral waters, etc. (Mathur et al.,2003).The sweetener may be sugar, high fructose corn syrup, fruit juice, sugar substitute(in the case of diet drinks)(Vaux and Golder,2003).The soft drink are mostly carbonated usually prepared from carbonated syrup containing sugar, flavoring essence, citric acid and a preservative, Sodium Benzoate (Ofori et al.,2013).Benzoic acid is mostly used as a preservative. 
World over, especially in Nigeria, soft drinks are consumed on a daily basis in large amount by both children and adults due to their characteristic taste, affordability and thirst-quenching potential. Soft drinks are usual beverages served at most functions and celebrations, such as marriages, naming of babies, funerals etc. in Nigeria and other places. The hot weather conditions in Nigeria also contributes to the high consumption of soft drinks. The increasing demand for food safety is stimulating research regarding the benefit and risks associated with consumption of foodstuffs and drinks (Magomya et al., 2015).

Therefore, the determination of levels of essential and toxic metals in commercial soft drinks in terms of safety and nutritional aspects has been considered (Fathabad et al., 2018; Salma et al.,2015).

Polycyclic aromatic hydrocarbons (PAHs) on the other hand, are an important group of major environmental concern. There are several possible sources of PAHs in the environment, anthropogenic activities are, however, considered as major sources, petrogenic and pyrolytic sources are considered to be the most important. More than 100 PAHs have been characterized, 16 of which were classified by United State Environmental Protection Agency (USEPA) as priority pollutants because of their toxicity (USEPA1993).PAHs have been reported to be highly mutagenic and carcinogenic in humans (Simko,2002).Dietary exposures are the major sources of human exposure. PAHs contamination is from food processing techniques like curing, drying, smoking, toasting, grilling, barbecuing and refining. These food processing steps are known to generate and increase the level of PAHs in food (Scientific Committee on food, 2002). The toxicity of PAHs is structure dependent. PAHs are known for their carcinogenic, mutagenic, and teratogenic properties. More than $80 \%$ of the total PAHs contribution to environmental and health concerns could be attributed to the 16 EPA priority PAHs. Carcinogenic nature of these compounds is a major worry, although not all of them are affected (Kumar et al.,2014). The most common PAH that causes cancer in laboratory animals is benzo[a]pyrene. Ingestion of high levels of these compounds during pregnancy could result in birth defects and decreased body weight of the offspring. Most of the PAHs are not genotoxic by themselves; they need to be metabolized to the diol epoxides which react with DNA, thus inducing genotoxic damage (Brazkova,2013).Occupational exposure to high levels of mixtures containing PAHs have resulted in symptoms such as eye irritation, nausea, vomiting, diarrhea and confusion(Zhong and Wang,2002).

More so, long term consumption of food and beverage(soft drinks) contaminated with large quantities of toxic metals may lead to chronic accumulation that can cause heart diseases, Kidney ,neurological disorders, various form of cancer, morphological abnormalities, growth retardation, increased mortality and genetic effects in humans(Fathabad et al.,2018).Among these metals, $\mathrm{Pb}, \mathrm{Cd}, \mathrm{Hg}$ and $\mathrm{As}$ can be accounted for as major threats to human even in small quantities (Adegbola et al.,2015;Ahmadi and Ziarati,2015;Akan et al.,2013).

Since these soft drinks are consumed on daily basis by people of all ages, especially the youth, these chemical pollutants might accumulate overtime. if these chemical pollutants are not checked, dire consequence will ensure. Hence this study aims at: (1) determining the levels of toxic metals( $\mathrm{As}, \mathrm{Cd}, \mathrm{Hg}$ and $\mathrm{Pb}$ ) and Polycyclic aromatic hydrocarbons(PAHs) in 16 samples from four types of commercial soft drinks commonly consumed among Nnamdi Azikiwe University students (2019) by the aid of Atomic Absorption Spectroscopy(AAS) and Gas Chromatography with Flame ionization detector(GC-FID),(2) assessing the potential human health risk(both carcinogenic and non-carcinogenic), and (3) to compare the concentrations of the metals and PAHs with the permissible limits set by regulatory bodies.

\section{Experimental}

\subsection{Collection of soft drink samples}

For this study, 16 commercial soft drink samples (soda drink and malt based drink [non-alcoholic beer], and yoghurt) of four different brands were randomly purchased from valid retail outlets in Awka, Anambra State, between August and September 2019.

\subsection{Metal analysis}

The concentrations of the metals, $\mathrm{Pb}, \mathrm{Cd}, \mathrm{As}$ and $\mathrm{Hg}$ in the digested samples were determined using Atomic absorption spectrophotometer (Solaar SE 7190). Calibration standards for AAS analysis were prepared for each metals. A calibration curve of absorption versus concentration was plotted for each metal and used for the determination of the concentrations in the samples. 50ml of each sample was measured into a clean digestion flask. $10 \mathrm{ml}$ concentrated nitric acid was added, and the mixture was heated on a hot plate until brown fumes disappear. The mixture was allowed to cool and $50 \mathrm{ml}$ of distilled water added. It was then filtered and made up to mark in a $100 \mathrm{ml}$ volumetric flask.

\subsection{PAHs analysis}

\subsubsection{Extraction and analysis}

Extraction was carried out in a liquid extraction mode by thoroughly shaking $50 \mathrm{ml}$ of the sample in a separating funnel with $25 \mathrm{ml}$ of methylene chloride. The solution was transferred to a separating funnel and the samples were extracted by shaking the funnel for $2 \mathrm{~min}$ with periodic venting to release pressure. The organic layer was allow to separate from the sample phase for a minimum of $10 \mathrm{~min}$ and the methylene chloride was collected in a $250 \mathrm{ml}$ flask. Extraction was repeated three times and the extracts were combined in Erlenmeyer flask. The concentrated extract was obtained by evaporating the organic layer under gentle stream of nitrogen and stored in the refrigerator at $4^{\circ} \mathrm{c}$. The isolation of PAHs was done by solid-phase extraction in a normal phase mode. Activated silica gel was loaded into a glass-chromatographic column; additional $1 \mathrm{~g}$ of $\mathrm{Na}_{2} \mathrm{SO}_{4}$ was added to the column and conditioned with methylene chloride. The concentrated extract were dissolved in $5 \mathrm{ml}$ methylene chloride, loaded into the column and then eluted with $20 \mathrm{ml}$ methylene chloride. The elements were concentrated using a rotary evaporator and then reconstituted in $1 \mu 1$ methylene chloride for flame ionization detector gas chromatography analysis.

\subsubsection{Chromatographic analysis}

The samples were analyzed for naphthalene(Nap), acenaphthylene(Acy), acenaphthene(Ace), fluorine(Fl), phenanthrene(Phe), anthracene(Ant), fluoreanthene(Flu), pyrene(Pyr), benzo[a]anthracene(BaA), chrysene(Chy), benzo[b]fluoranthene(BbF), benzo[k]fluoranthene(BkF), benzo[a]pyrene(BaP), benzo[g,h,i]perylene(BghiP),Dibenz[a,h]anthracene(DahA) and indeno[1,2,3cd]pyrene(IcdP). Corresponding results were obtained using Gas chromatography (GC Agilent $6890 \mathrm{~N}$ with Flame Ionization detection [GC-FID]).The GC was programmed as follows: initial temperature of $60^{\circ} \mathrm{c}$ for $2 \mathrm{~min}$ and ramped at $25^{\circ} \mathrm{c} / \mathrm{min}$ to $300^{\circ} \mathrm{c}$ for $5 \mathrm{~min}$ and allowed to stay for $15 \mathrm{~min}$ giving a total of run time of $22 \mathrm{mins}$.A $1 \mu 1$ volume split less injection port temperature was used and injection 
port temperature was set at $250^{\circ} \mathrm{c}$, while $300^{\circ} \mathrm{c}$ was maintained for the injection port of the FID detector. A standard mixture of 16 priority PAHs (listed above) was obtained and used for the analysis. Compounds were identified by comparing the retention time of the standards with that obtained from the extracts and individual analysis of PAHs were used for quantitation.

\subsection{Human health risk assessment}

Risk assessment was done based on the mean concentration of carcinogenic and non-carcinogenic metals determined in the soft drinks using United State Environmental Protection Agency (USEPA) human health risk assessment models (Liu,et al,2013).

\subsection{Estimated daily intake}

The daily intake of metals depend on the metal concentration in the soft drink, the daily soft drink intake, and the body weight. The estimated daily intake (EDI) of metals is a concept introduced to take into account these factors. The EDI was calculated based on the following formula (Sharma et al., 2010).

$\mathrm{EDI}=\mathrm{C}_{\text {metal }} \times \mathrm{DI} / \mathrm{BW}$

Where $\mathrm{C}$ is the metal concentration in the soft drink in $\mathrm{mg} / \mathrm{l}, \mathrm{D}$ is the daily intake of the soft drink in liters person ${ }^{-1}$ and $\mathrm{BW}$ is the average body weight in $\mathrm{kg}$ (70kg adults).

\subsection{Non-Carcinogenic Risk}

\subsubsection{Target hazard quotient (THQ)}

Non carcinogenic risk estimation of heavy metals consumption was determined using THQ values. THQ is a ratio of the determined dose of a pollutant to a reference level considered harmful. THQ values were determined based on the following formula (Sharma et al., 2010).

$\mathrm{THQ}=\mathrm{Efr} \times \mathrm{Ed} \times \mathrm{FIR} \times \mathrm{C} / \mathrm{RFD} \times \mathrm{BW} \times \mathrm{Atn} \times 10^{-3}$

Where Efr is exposure frequency assumed to be 365 days year ${ }^{-1}$,ED is exposure duration in 56 years equivalent to an average lifetime, FIR is average daily consumption in $\mathrm{kg}_{\text {person }}{ }^{-1} \mathrm{day}^{-1}, \mathrm{C}$ is concentration of metal in soft drink sample in mg/l, RFD is reference dose in $\mathrm{mg} / \mathrm{kg} / \mathrm{day}$, and ATn is average exposure time for carcinogens.

\subsubsection{Chronic hazard index (HI)}

The reference dose for each heavy metals in this current study are $0.0003,0.004,0.001$ and 0.001 for As, $\mathrm{Pb}, \mathrm{Cd}$ and $\mathrm{Hg}$ respectively. The chronic hazard index (HI) is the sum of more than one hazard quotient for multiple toxicants or multiple exposure pathways; it was calculated using the equation below:

$\mathrm{HI}=\sum \quad \mathrm{THQ}$

\subsection{Carcinogenic risk}

Cancer risk can be evaluated from

Cancer risk $=\mathrm{CDI} \times \mathrm{SF}$

Where cancer risk represents the probability of an individual lifetime health risks from carcinogens; CDI is the chronic daily intake of carcinogens $\left(\mathrm{mgkg}^{-1} \mathrm{~d}^{-1}\right)$; $\mathrm{sF}$ is the slope factor of hazardous substance $\left(\mathrm{mgkg}^{-1} \mathrm{~d}^{-1}\right)$.

The cumulative cancer risk can be calculated from

Total cancer risk $=\sum \quad \mathrm{CDI} \times \mathrm{SF}$

Where CDI is the chronic daily intake $\left(\mathrm{mgkg}^{-1} \mathrm{~d}^{-1}\right)$; SF is the slope factor. The acceptable or tolerable risk for regulatory purposes is within the range of $10^{-6}-10^{-4}$ (USEPA,2002).

\subsection{Questionnaire}

A questionnaire, detailing the demographic characteristic (Age, gender, educational level and amount of soft drink taken daily) of participants was administered.

\section{Results}

The concentration $(\mathrm{mg} / \mathrm{l})$ of the heavy metals $(\mathrm{Pb}, \mathrm{Cd}, \mathrm{As}$ and $\mathrm{Hg}$ ) analyzed in the soft drink samples is presented in Table 1 .

From the analysis of results of the levels of the heavy metals observed, the range of the metals follow this order: $\mathrm{Pb}(0.0147-$ $2.9653 \mathrm{mg} / \mathrm{l}), \mathrm{Cd}(0.011-1.863 \mathrm{mg} / \mathrm{l}), \mathrm{As}(0.0012-0.3234 \mathrm{mg} / \mathrm{l})$ and $\mathrm{Hg}(0.0012-0.0060 \mathrm{mg} / \mathrm{l})$. Among the four different metals analyzed in the soft drink, the highest mean level was $0.6116 \mathrm{mg} / \mathrm{l}(\mathrm{Pb})$ and the lowest was $0.0028 \mathrm{mg} / \mathrm{l}(\mathrm{Hg}$ ) (Table 1).The mean levels of the metals increased in this order: $\mathrm{Hg}<\mathrm{As}<\mathrm{Cd}<\mathrm{Pb}$. About $81.25 \%$ of the samples had $\mathrm{Hg}$ level below detection limit, and $18.75 \%$ above detectable limits, $18.25 \%$ of the samples had Pb below detection limit, and $81.75 \%$ above detectable limits. $68.75 \%$ of the samples had As within 
detectable limits. The remaining $31.25 \%$ was below detection limit. $56.25 \%$ of the samples did not show Cd while $43.75 \%$ of the samples had Cd detected.

Table 1: Heavy Metal Concentration $(\mathrm{Pb}, \mathrm{Cd}, \mathrm{As}$ and $\mathrm{Hg})$ in Soft Drink Samples $(\mathrm{Mg} / \mathrm{L})$

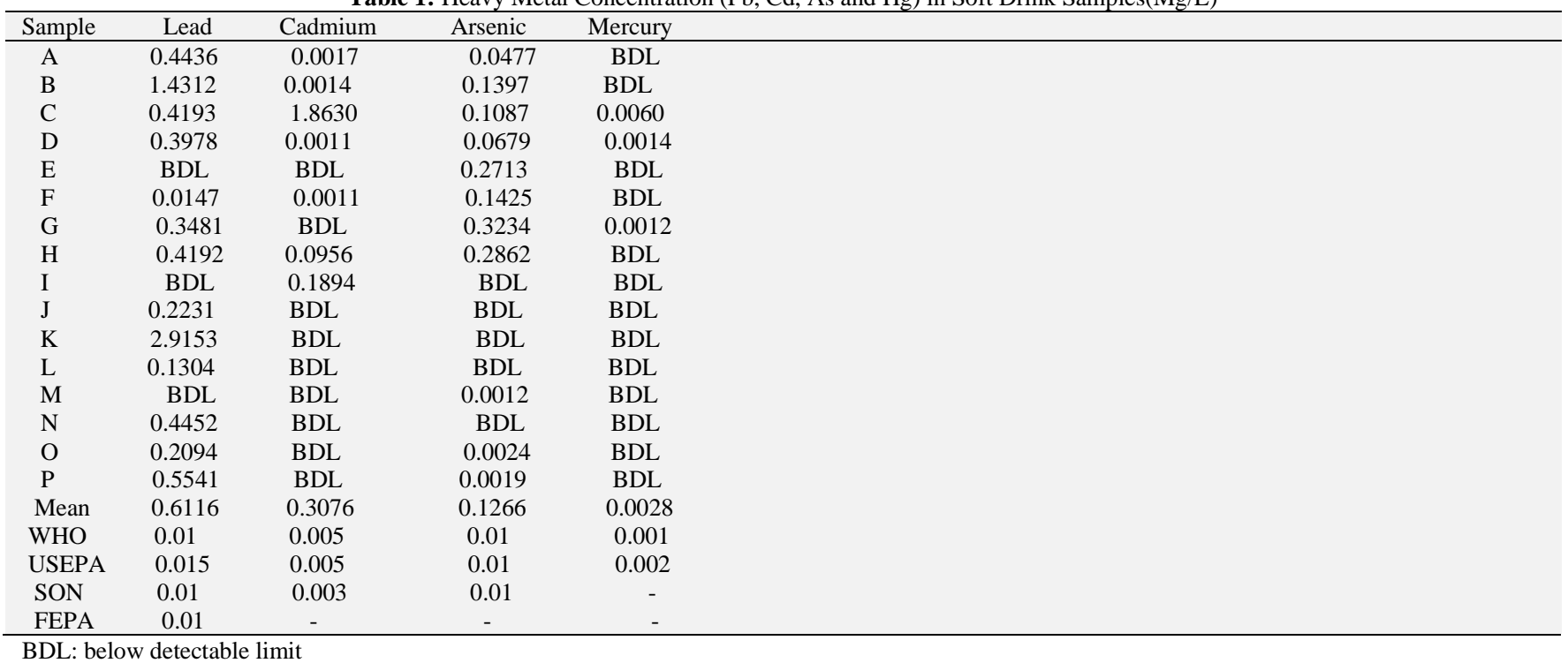

BDL: below detectable limit

\subsection{Human health risk assessment}

The EDI of the toxic metals in the soft drink samples collected from Awka is shown in Table 2. The EDI of these heavy metals (HMs) follow this order. $\mathrm{Pb}\left(5.7 \times 10^{-6}-1.6 \times 10^{-2}\right), \mathrm{Cd}\left(9.7 \times 10^{-6}-1.06 \times 10^{-2}\right), \mathrm{As}\left(5.7 \times 10^{-6}-1.5 \times 10^{-3}\right)$ and $\mathrm{Hg}\left(5.7 \times 10^{-6}-3.43 \times 10^{-5}\right)$.The mean levels of the metals decrease in this order $\mathrm{Pb}>\mathrm{Cd}>\mathrm{As}>\mathrm{Hg}$.

The Estimated target quotient (THQ) and Hazard Index (HI) of the selected heavy metals through the consumption of soft drink in this present study, is presented in Table 3.The HMs concentration of soft drink samples increase in this order: Hg (0.0057$0.0343)<\mathrm{Pb}(0.0014<4.15)<\mathrm{As}(0.019-6.0)$ and $\mathrm{Cd}(0.0097-10.6) .93 .75 \%$ of the sample had $\mathrm{Pb}$ THQ $<1(\mathrm{Table})$, while, $37.5 \%$ of the samples had As THQ $>1 . \mathrm{Hg}$ had THQ<1(Table 3). In addition, the HI of the combined risk of heavy metals toxicity was higher than unity (HI $>1$ ) in about $62.5 \%$ of the samples (Table 3 ).

The ILCR of the metals( $\mathrm{As}, \mathrm{Pb}$ and $\mathrm{Cd}$ ) due to exposure from the ingestion of the soft drink samples are presented in Table 4.The cancer risk computed in this present study was highest in $\mathrm{Pb}\left(4.85 \times 10^{-8}-1.41 \times 10^{-4}\right)$, followed by $\mathrm{Cd}\left(3.59 \times 10^{-5}-6.67 \times 10^{-2}\right)$. That of $\mathrm{As}$ is $\left(8.55 \times 10^{-6}-2.7 \times 10^{-3}\right)($ Table 4$)$.

\subsection{Polycyclic aromatic hydrocarbons}

The summary of the analysis of results of the PAHs congeners is presented in Table 5.

In this present study, the total PAHs congener's range from $0.000-4.731 \mathrm{mg} / \mathrm{l}$. The highest level of PAHs was found in sample $\mathrm{F}(4.009 \mathrm{mg} / \mathrm{l})($ Table 5), while the lowest value was found in sample $\mathrm{J}(0.000 \mathrm{mg} / \mathrm{l})($ Table 5$) .50 \%$ of the sample had no detectable PAHs congeners. Benzo(a)pyrene was not detected in all the samples (Table 5).

Table 2: Estimated Daily Intake of Metals ( $\mathrm{Mg} / \mathrm{Kg} / \mathrm{Day})$ Base on Soft Drink Consumption by Adults

\begin{tabular}{lllll}
\hline Samples & $\mathbf{P b}$ & \multicolumn{1}{c}{$\mathbf{C d}$} & \multicolumn{1}{c}{$\mathbf{A s}$} & $\mathbf{H g}$ \\
\hline $\mathrm{A}$ & $2.5 \times 10^{-3}$ & $9.7 \times 10^{-6}$ & $2.7 \times 10^{-4}$ & $5.7 \times 10^{-6}$ \\
$\mathrm{~B}$ & $8.2 \times 10^{-3}$ & $8.0 \times 10^{-6}$ & $7.9 \times 10^{-4}$ & $5.7 \times 10^{-6}$ \\
$\mathrm{C}$ & $2.4 \times 10^{-3}$ & $1.06 \times 10^{-2}$ & $6.2 \times 10^{-4}$ & $3.43 \times 10^{-5}$ \\
$\mathrm{D}$ & $2.3 \times 10^{-3}$ & $3.9 \times 10^{-4}$ & $3.9 \times 10^{-4}$ & $8.0 \times 10^{-6}$ \\
$\mathrm{E}$ & $5.7 \times 10^{-6}$ & $5.7 \times 10^{-6}$ & $1.5 \times 10^{-3}$ & $5.7 \times 10^{-6}$ \\
$\mathrm{~F}$ & $8.0 \times 10^{-6}$ & $8.1 \times 10^{-4}$ & $8.1 \times 10^{-4}$ & $8.0 \times 10^{-6}$ \\
$\mathrm{G}$ & $1.9 \times 10^{-3}$ & $5.7 \times 10^{-6}$ & $1.8 \times 10^{-3}$ & $5.7 \times 10^{-6}$ \\
$\mathrm{H}$ & $2.4 \times 10^{-3}$ & $5.4 \times 10^{-4}$ & $1.6 \times 10^{-3}$ & $5.7 \times 10^{-6}$ \\
$\mathrm{I}$ & $5.7 \times 10^{-6}$ & $1.0 \times 10^{-3}$ & $5.7 \times 10^{-6}$ & $5.7 \times 10^{-6}$ \\
$\mathrm{~J}$ & $1.2 \times 10^{-3}$ & $5.7 \times 10^{-6}$ & $5.7 \times 10^{-6}$ & $5.7 \times 10^{-6}$ \\
$\mathrm{~K}$ & $1.6 \times 10^{-2}$ & $5.7 \times 10^{-6}$ & $5.7 \times 10^{-6}$ & $5.7 \times 10^{-6}$ \\
$\mathrm{~L}$ & $7.4 \times 10^{-4}$ & $5.7 \times 10^{-6}$ & $5.7 \times 10^{-6}$ & $5.7 \times 10^{-6}$ \\
M & $5.7 \times 10^{-6}$ & $5.7 \times 10^{-6}$ & $5.7 \times 10^{-6}$ & $5.7 \times 10^{-6}$ \\
$\mathrm{~N}$ & $2.5 \times 10^{-3}$ & $5.7 \times 10^{-6}$ & $5.7 \times 10^{-6}$ & $5.7 \times 10^{-6}$ \\
$\mathrm{O}$ & $1.1 \times 10^{-3}$ & $5.7 \times 10^{-6}$ & $1.37 \times 10^{-5}$ & $5.7 \times 10^{-6}$ \\
$\mathrm{P}$ & $3.1 \times 10^{-3}$ & $5.7 \times 10^{-6}$ & $5.7 \times 10^{-6}$ & $5.7 \times 10^{-6}$ \\
Mean & $2.7 \times 10^{-3}$ & $8.3 \times 10^{-4}$ & $4.8 \times 10^{-4}$ & $7.7 \times 10^{-6}$ \\
\hline
\end{tabular}


Table 3: Estimated Target Hazard Quotients (THQ) of Heavy Metals from the Consumption of Soft Drink for Adults

\begin{tabular}{llllll}
\hline Samples & $\mathrm{Pb}$ & $\mathrm{Cd}$ & $\mathrm{As}$ & $\mathrm{Hg}$ & $\mathrm{HI}=\sum \mathrm{THQ}$ \\
\hline $\mathrm{A}$ & 0.625 & 0.0097 & 0.9 & 0.0057 & 1.5404 \\
$\mathrm{~B}$ & 2.050 & 0.008 & 2.63 & 0.0057 & 4.6937 \\
$\mathrm{C}$ & 0.600 & 10.6 & 2.06 & 0.0343 & 13.2943 \\
$\mathrm{D}$ & 0.575 & 0.006 & 1.3 & 0.008 & 1.889 \\
$\mathrm{E}$ & 0.0014 & 0.0057 & 5.0 & 0.0057 & 5.0128 \\
$\mathrm{~F}$ & 0.002 & 0.81 & 2.7 & 0.008 & 3.52 \\
$\mathrm{G}$ & 0.475 & 0.0057 & 6.0 & 0.0057 & 6.4864 \\
$\mathrm{H}$ & 0.600 & 0.54 & 5.3 & 0.0057 & 6.4457 \\
$\mathrm{I}$ & 0.0014 & 1.0 & 0.019 & 0.0057 & 1.0261 \\
$\mathrm{~J}$ & 0.30 & 0.0057 & 0.019 & 0.0057 & 0.3304 \\
$\mathrm{~K}$ & 4.150 & 0.0057 & 0.019 & 0.0057 & 4.1804 \\
$\mathrm{~L}$ & 0.185 & 0.0057 & 0.019 & 0.0057 & 0.2154 \\
$\mathrm{M}$ & 0.0014 & 0.0057 & 0.019 & 0.0057 & 0.0318 \\
$\mathrm{~N}$ & 0.625 & 0.0057 & 0.019 & 0.0057 & 0.6554 \\
$\mathrm{O}$ & 0.270 & 0.0057 & 0.045 & 0.0057 & 0.3264 \\
$\mathrm{P}$ & 0.770 & 0.0057 & 0.019 & 0.0057 & 0.8004 \\
\hline
\end{tabular}

Table 4: Carcinogenic Risk of Heavy Metals in the Selected Soft Drink Samples for Adults

\begin{tabular}{llll}
\hline Samples & $\mathrm{Pb}$ & $\mathrm{Cd}$ & $\mathrm{As}$ \\
\hline $\mathrm{A}$ & $2.13 \times 10^{-5}$ & $6.11 \times 10^{-5}$ & $1.45 \times 10^{-5}$ \\
$\mathrm{~B}$ & $6.97 \times 10^{-8}$ & $5.04 \times 10^{-5}$ & $1.18 \times 10^{-3}$ \\
$\mathrm{C}$ & $2.04 \times 10^{-5}$ & $6.67 \times 10^{-2}$ & $9.3 \times 10^{-4}$ \\
$\mathrm{D}$ & $1.95 \times 10^{-5}$ & $3.96 \times 10^{-5}$ & $5.85 \times 10^{-4}$ \\
$\mathrm{E}$ & $4.85 \times 10^{-8}$ & $3.59 \times 10^{-5}$ & $2.25 \times 10^{-3}$ \\
$\mathrm{~F}$ & $6.8 \times 10^{-5}$ & $5.10 \times 10^{-3}$ & $1.21 \times 10^{-3}$ \\
$\mathrm{G}$ & $1.62 \times 10^{-5}$ & $3.59 \times 10^{-5}$ & $2.7 \times 10^{-3}$ \\
$\mathrm{H}$ & $2.04 \times 10^{-5}$ & $3.4 \times 10^{-3}$ & $2.11 \times 10^{-3}$ \\
$\mathrm{I}$ & $4.85 \times 10^{-8}$ & $6.3 \times 10^{-3}$ & $8.55 \times 10^{-6}$ \\
$\mathrm{~K}$ & $1.41 \times 10^{-4}$ & $3.59 \times 10^{-5}$ & $8.55 \times 10^{-6}$ \\
$\mathrm{~L}$ & $6.29 \times 10^{-6}$ & $3.59 \times 10^{-5}$ & $8.55 \times 10^{-6}$ \\
$\mathrm{M}$ & $4.85 \times 10^{-8}$ & $3.59 \times 10^{-5}$ & $8.55 \times 10^{-6}$ \\
$\mathrm{~N}$ & $2.13 \times 10^{-5}$ & $3.59 \times 10^{-5}$ & $8.55 \times 10^{-6}$ \\
$\mathrm{O}$ & $9.35 \times 10^{-6}$ & $3.59 \times 10^{-5}$ & $2.06 \times 10^{-5}$ \\
$\mathrm{P}$ & $2.64 \times 10^{-5}$ & $3.59 \times 10^{-5}$ & $8.55 \times 10^{-6}$ \\
\hline
\end{tabular}

Table 5: A Summary of Analytical Results of the PAHs in Soft Drink Samples from Awka.

\begin{tabular}{|c|c|c|c|c|c|c|c|c|c|c|c|c|c|c|c|c|c|c|}
\hline $\begin{array}{l}\text { PAH } \\
\text { S }\end{array}$ & $\begin{array}{l}\text { No } \\
\text { of } \\
\text { Rin } \\
\text { gs }\end{array}$ & $\begin{array}{l}\text { A } \\
(\mathrm{mg} / \\
1)\end{array}$ & $\begin{array}{l}\text { B } \\
(\mathrm{mg} / \\
1)\end{array}$ & $\begin{array}{l}\text { Mol. } \\
\text { Wt } \\
(\mathrm{g} / \mathrm{m} \\
\mathrm{ol})\end{array}$ & $\begin{array}{l}\mathrm{C} \\
(\mathrm{mg} / \\
1)\end{array}$ & $\begin{array}{l}\mathrm{D} \\
(\mathrm{mg} / \\
1)\end{array}$ & $\begin{array}{l}\mathrm{E} \\
(\mathrm{mg} / \\
1)\end{array}$ & $\begin{array}{l}\mathrm{F} \\
(\mathrm{mg} / \\
1)\end{array}$ & $\begin{array}{l}\mathrm{G} \\
(\mathrm{mg} / \\
1)\end{array}$ & $\begin{array}{l}\mathrm{H} \\
(\mathrm{mg} / \\
1)\end{array}$ & $\begin{array}{l}\mathrm{I} \\
(\mathrm{mg} / \\
1)\end{array}$ & $\begin{array}{l}\text { J } \\
(\mathrm{m} / 1 \\
)\end{array}$ & $\begin{array}{l}\mathrm{K} \\
(\mathrm{mg} / \\
\mathrm{l})\end{array}$ & $\begin{array}{l}\mathrm{L} \\
(\mathrm{mg} / \\
1)\end{array}$ & $\begin{array}{l}\mathrm{M} \\
(\mathrm{mg} / \\
1)\end{array}$ & $\begin{array}{l}\mathrm{N} \\
(\mathrm{mg} / \\
1)\end{array}$ & $\begin{array}{l}\mathrm{O} \\
(\mathrm{mg} / \\
1)\end{array}$ & $\begin{array}{l}\mathrm{P} \\
(\mathrm{mg} / \\
1)\end{array}$ \\
\hline Nap & 2 & ND & ND & 128 & ND & ND & ND & ND & ND & ND & ND & ND & ND & ND & ND & ND & ND & ND \\
\hline Acy & 3 & ND & ND & 158 & ND & ND & ND & ND & ND & ND & ND & ND & ND & ND & ND & ND & ND & ND \\
\hline Ace & 3 & ND & $\begin{array}{l}0.00 \\
0\end{array}$ & 154 & ND & ND & ND & ND & ND & ND & ND & ND & ND & ND & ND & ND & ND & ND \\
\hline $\mathrm{Fl}$ & 3 & ND & $\begin{array}{l}0.00 \\
1\end{array}$ & 166 & ND & ND & ND & ND & ND & ND & ND & ND & ND & ND & $\begin{array}{l}0.02 \\
2\end{array}$ & ND & ND & ND \\
\hline Phe & 3 & ND & $\begin{array}{l}0.00 \\
2\end{array}$ & 178 & ND & ND & ND & ND & ND & ND & $\begin{array}{l}0.10 \\
2\end{array}$ & $\begin{array}{l}0.00 \\
0\end{array}$ & ND & ND & ND & ND & ND & ND \\
\hline Ant & 3 & ND & $\begin{array}{l}0.00 \\
0\end{array}$ & 178 & ND & ND & ND & ND & ND & ND & ND & ND & ND & ND & ND & ND & ND & ND \\
\hline Flu & 3 & ND & $\begin{array}{l}0.00 \\
0\end{array}$ & 202 & $\begin{array}{l}0.00 \\
1\end{array}$ & ND & ND & ND & ND & ND & ND & ND & ND & ND & $\begin{array}{l}0.01 \\
7\end{array}$ & ND & ND & $\begin{array}{l}0.00 \\
2\end{array}$ \\
\hline Pyr & 4 & ND & ND & 202 & ND & ND & ND & ND & ND & ND & ND & ND & ND & ND & $\begin{array}{l}0.01 \\
9\end{array}$ & ND & ND & ND \\
\hline $\mathrm{BaA}$ & 4 & ND & $\begin{array}{l}0.00 \\
0\end{array}$ & 228 & ND & ND & ND & ND & ND & ND & ND & ND & ND & ND & $\begin{array}{l}0.08 \\
8\end{array}$ & ND & ND & ND \\
\hline Chy & 4 & ND & ND & 228 & ND & ND & ND & ND & ND & ND & ND & ND & ND & ND & $\begin{array}{l}0.02 \\
03\end{array}$ & ND & ND & ND \\
\hline $\mathrm{BaP}$ & 5 & ND & ND & 252 & ND & ND & ND & ND & ND & ND & ND & ND & ND & ND & ND & ND & ND & ND \\
\hline $\mathrm{BbF}$ & 5 & ND & ND & 252 & ND & ND & ND & ND & $\begin{array}{l}0.36 \\
8\end{array}$ & ND & ND & ND & ND & ND & $\begin{array}{l}0.00 \\
4\end{array}$ & ND & $\begin{array}{l}0.17 \\
8\end{array}$ & ND \\
\hline $\mathrm{BkF}$ & 5 & ND & $\begin{array}{l}0.00 \\
0\end{array}$ & 252 & ND & ND & ND & ND & $\begin{array}{l}0.21 \\
2\end{array}$ & ND & ND & ND & ND & ND & ND & ND & ND & ND \\
\hline $\begin{array}{l}\text { Dah } \\
\text { A }\end{array}$ & 6 & ND & ND & 276 & ND & ND & ND & ND & ND & ND & ND & ND & ND & ND & ND & ND & ND & ND \\
\hline $\begin{array}{l}\text { Bghi } \\
\text { P }\end{array}$ & 6 & ND & ND & 276 & ND & ND & ND & ND & $\begin{array}{l}0.14 \\
1\end{array}$ & ND & ND & ND & ND & ND & ND & ND & ND & ND \\
\hline Icdp & 6 & ND & ND & 276 & ND & ND & ND & ND & $\begin{array}{l}4.00 \\
9\end{array}$ & ND & ND & ND & ND & ND & $\begin{array}{l}0.09 \\
4\end{array}$ & ND & ND & ND \\
\hline$\sum \mathrm{PA}$ & & & 0.00 & & 0.00 & & & & 4.73 & & 0.10 & 0.00 & & & 0.02 & & 0.17 & 0.00 \\
\hline $\mathrm{H}$ & & & 3 & & 1 & & & & 1 & & 2 & 0 & & & 1 & & 8 & 2 \\
\hline
\end{tabular}

ND: Not detectable 
Table 6:

The European Community (EC) (European Communities,1998) and United State Environmental Protection Agency (USEPA) (USEPA,2002)

Standards for some PAHs in drinking water are presented in Table 6.

\begin{tabular}{lll}
\hline PAHs & EC(1998) \\
\hline Naphthalene & - & \\
Acenaphthylene & - & USEPA(2002) \\
Acenaphthene & - & - \\
Fluorene & - & - \\
Phenanthrene & - & \\
Anthracene & 0.00003 & 0.0002 \\
Fluoranthene & - & \\
Pyrene & - & \\
Benzo(a)anthracene & - & -0002 \\
Chrysene & 0.00003 \\
Benzo(b)fluoranthene & 0.00003 \\
Benzo(k)fluoranthene & 0.00003 \\
Benzo(a)pyrene & 0.00003 \\
Indeno(1,2,3-cd)pyrene & - & 0.0002 \\
Dibenzo(a,h)anthrancene & 0.00003 \\
Benzo(g,h,i)perylene & 0.0002 \\
\hline MCL-Maximum contaminant level, EC-European Community, USEPA-United States Environmental Protection Agency & 0.0002 \\
\hline
\end{tabular}

MCL-Maximum contaminant level, EC-European Community, USEPA-United States Environmental Protection Agency

\section{Discussion}

\subsection{The concentration of essential and toxic metals}

Assessing the levels of heavy metals in soft drink is essential for consumer safety because these soft drinks are vastly consumed worldwide (Dehelean and Magdas, 2013). The composition of heavy metals in soft drinks is very essential because of the toxic nature. Fe, $\mathrm{Cu}$, $\mathrm{Cr}, \mathrm{Pd}$ and $\mathrm{Hg}$ are toxic in certain quantities (Dehelean and Magdas,2013).Several works have been done on heavy metals :(AdepojuBellow et al.,2012;Krejpcio et al.,2005;Bingol et al.,2010;Nabi et al.,2020).In this present study ,we compared the level of the toxic metals obtained in the studied soft drinks with the international organization WHO(WHO,2006) and USEPA(USEPA,2012) and Local organization ,SON(SON,2002) and FEPA(FEPA,1991) standards. The concentration of $\mathrm{Pb}$ in the soft drink were higher than the limit set by USEPA, WHO, FEPA and SON. In contrast, the concentration of $\mathrm{Hg}$ in soft drink were found to be lower than the limit set by USEPA and WHO.50\% of the samples had As levels higher than the safe limit set by USEPA,WHO and SON. Only $18.75 \%$ of the soft drinks samples had Cd level higher than the limit set by WHO, SON and USEPA.

Al-Mudaf et al., (2016) reported As, $\mathrm{Pb}$ and Cd levels detectable in 50\%, 90\% and 95\% respectively, of soft drink analysed, while the other metals were in $100 \%$ of the soft drinks samples. All 25 metals were found lower than the limit set by USEPA and WHO. The result obtained by Ogunlana et al.,(2015) showed that the concentration of heavy metal in $30 \%$ of the samples they analyzed was in agreement to WHO permissible limit and the concentration in $70 \%$ of the samples were higher than the safe limits. The levels of $\mathrm{Zn}, \mathrm{As}, \mathrm{Ca}, \mathrm{Co}, \mathrm{Pb}$ and $\mathrm{Fe}$, in the soft drinks were $0.190-2.280,0.001-0.016,0.001-0.01,0.040-0.790,0.001-0.040$ and $0.080-0.550 \mathrm{mg} / \mathrm{l}$, respectively, in their study done in Nigeria. However, in this study, the percentage detection of $\mathrm{Pb}$. $\mathrm{Hg}$, $\mathrm{As}$, and $\mathrm{Cd}$ is $81.75 \%, 18.75 \%, 68.75 \%$ and $43.75 \%$ respectively. $81.5 \%$ of the samples had $\mathrm{Pb}$ above acceptable limits and for $\mathrm{Cd}(18.75 \%)$, As $(43.75 \%), \mathrm{Hg}(6.25 \%)$

While Adepoju-Bello (2012) reported the highest lead level of $0.0002 \mathrm{mg} / \mathrm{l}$ that is well below the WHO, Son, and FEPA upper limits in their study in Lagos, Nigeria, however Maduabuchi et al., and Krejpcio et al.had upper limits in excess of the reference upper limits. In our own study both the mean value and the upper range are all well above the acceptable permissible limits. These differences in lead concentration in the soft drinks may most likely be attributable to urbanization consequences and the attendant pollution, and the degree of the amount of leached metals in the water used for the soft drink production. Sample size and type of brand may also contribute to the observed differences (Nabit et al, 2020).

The concentrations of $\mathrm{Hg}$ in all the soft drink samples range from $0.0012-0.0060 \mathrm{mg} / \mathrm{l}$ in this present study with a mean value of $0.0028 \mathrm{mg} / \mathrm{l}$, which is higher than the acceptable levels of $0.001 \mathrm{mg} / 1$ and $0.002 \mathrm{mg} / 1$ of WHO and USEPA, respectively .This value is quite lower than the values detected for $\mathrm{Hg}$ in fruit juices and soft drink samples $(2.39 \mu \mathrm{g} / 1[0.00239 \mathrm{mg} / \mathrm{l}])$ as reported by Robert and Orisakwe. Exposure to mercury even in small amount may cause serious health problems. Long term exposure to Hg increases the risk of skin, long, urinary bladder and kidney cancer (Fang et al., 2010). In addition, Nabi et al., (2020), reported Hg levels to be below detectable limit. Again, differences in brand types, methods of analysis, and environmental contamination may account for these observed differences.

The levels of As in this study range from 0.0012 to $0.3234 \mathrm{mg} / \mathrm{l}$, with a mean of $0.1266 \mathrm{mg} / \mathrm{l}$. The value in this study are higher than that observed by Bingol et al., (2010). Bingol et al., (2010) had reported As levels as $0.11 \mathrm{mg} / \mathrm{l}$ in a study of 104 canned soft drink in Turkey. The high level of As in our study probably may due to urban atmospheric area, industrial background, surface water used for production of soft drink or the steps employed during the soft drink processing (Magomya et al., 2015). However, Asheraf et al., (2000), reported arsenic levels as $0.837 \mathrm{mg} / \mathrm{l}$ in 34 soft drinks in Pakistan. These findings showed higher rates in comparison with our study. The high level of As in their study might be as a result of the level of contamination of the surface or ground water used, ingredients used, packaging or the site where the production took place (Pofahl et al.,2005, Nabi et al.,2020), since soft drink produced in an highly industrialized area may contain high metal ion load(Hague et al.,2008; Nagajyoti, et al.,2010).

Cadmium levels on the other hand, ranges from $0.011-1.863 \mathrm{mg} / \mathrm{l}$, with a mean of $0.307 \mathrm{mg} / \mathrm{l}$, which is comparable with the study of Maduabuchi etal. (2006) In Lagos Nigeria 0.003-0.081mg/l). Both studies show values higher than the acceptable limits. However, 
Ubong et al., (2016), reported Cd levels of $<0.001 \mathrm{mg} / \mathrm{l}$, in carbonated soft drinks in Nigeria. More so, Bingol et al., (2010), reported cadmium levels of 0.0001-0.011(0.005 \pm 0.0003$) \mathrm{ppm}$ in soft drinks in Turkey. Again environmental and processing differences may account for this.

\subsection{Human health risk assessment}

The Estimated daily intake (EDI) values of $\mathrm{Hg}$ in all the samples were within the Reference dose (RDF) of $0.001 \mathrm{mg} / \mathrm{kg} / \mathrm{d}$ for $\mathrm{Hg} . \mathrm{Thus}$, poses no health risk to the populace exposed to the soft drink. Cd in the samples had its EDI values lower than the RFD of $0.001 \mathrm{mg} / \mathrm{kg} / \mathrm{d}$ (Table 2), and thus, poses no potential health risk. 18.75\% of the samples had As EDI levels higher than the reference dose (RFD) of $0.0003 \mathrm{mg} / \mathrm{kgh} / \mathrm{d}$. Most of the samples had Pb EDI values within the RFD of $0.004 \mathrm{mg} / \mathrm{kg} / \mathrm{d}$. Thus, poses no potential health risk to the populace exposed to the soft drinks.

It must be known that the THQ values does not offer quantitative evaluation of the possibility of an exposed population facing a adverse health effects, but rather they function as a suggestion of the risk level due to metal exposure. The analysis of the THQ is binary, that is, THQ is either $>1$ or $<1$ implying that there is a reason for health concern. However, THQ values are additive and not multiplicative, for instance, the level of concern at THQ of 20 is greater but not tenfold as those of THQ of 2(Hague et al.,2008).

From this present study the levels of $\mathrm{Hg}$ in all the studied samples had its $\mathrm{THQ}<1$, and thus, poses no health risk to the populace exposed to the soft drink samples. $43.75 \%$ of the samples have As THQ greater than unity.75\% of the samples have Pb THQ $>1$, and thus poses a health risk.

$\mathrm{HI}$ in about $62.5 \%$ of the samples was higher than unity (HI>1) (Table3), and thus is of public health concern to the populace exposed to the soft drink.

The computed values for ILCR for $\mathrm{As}, \mathrm{Pb}$ and $\mathrm{Cd}$ due to the exposure from the ingestion of the soft drink samples are presented in Table 4.The range of the individual metal carcinogenic risk are $\mathrm{Pb}\left(4.85 \times 10^{-8}-1.41 \times 10^{-4}\right), \mathrm{Cd}\left(3.59 \times 10^{-5}-6.67 \times 10^{-2}\right)$, and $\mathrm{As}\left(8.55 \times 10^{-6}-2.7 \times 10^{-}\right.$ $\left.{ }^{3}\right)$.In general, USEPA recommended the permissible level for cancer risk to be lower than or about 1 chance in 1,000,000 lifetime exposure (ILCR $<1$ ) and this value is sometimes negligible. Threshold risk limit (ILCR $>10^{-4}$ ) for a chance of cancer is higher than 1 in 10,000 exposures where corrective methods can be applied. However, values of ILCR lying between $10^{-6}$ and $10^{-4}$ are considered as acceptable range. Moderate risk level (ILCR $>10^{-3}$ ) and (ILCR $>10^{-2}$ ) that is above 1 in 1000 and 1 in 100 respectively are considered unacceptable and the health safety of the public is of concern (Arigbede et al.,2019). From all the samples analysed, $6.25 \%$ of the samples had $\mathrm{Pb}$ cancer risk index above the permissible range, while for $\mathrm{As}$ and $\mathrm{Cd}, 31.25 \%$ and $25 \%$ had cancer risk index above permissible limits respectively as set by USEPA. Therefore, the consumption of the soft drink in this present study,pose health risk to the populace exposed to these soft drinks. Due to the higher ILCR values for both $\mathrm{Cd}$ and $\mathrm{As}$. Pb, As and $\mathrm{Cd}$ are classified by international Agency for Research on cancer (IARC) as being carcinogenic. Chronic exposure to low doses of $\mathrm{Pb}, \mathrm{Cd}$ and As could therefore result into many cancers (Jarup,2003).

\subsection{Polycyclic aromatic hydrocarbons (PAHs)}

PAHs have long been proposed by USEPA in 1984 as carcinogenic or mutagenic compounds and adopted by the US government in 1998.These ubiquitous organic compounds can be readily found in food(Martorell et al.,2010); air(Halek et al.,2006);soil(MaliszewskaKordybach et al.,2009);street dust(Perra et al.,2011) and rain water(Lorenzi et al.,2011).Some PAHs and their derivatives are highly toxic . Their mutagenic or carcinogenic properties are major risks to human health (Prycek et al.,2007).In this present study,the concentration of the PAHs were compared with the guidelines set by EU (EU,1998) and USEPA (USEPA,2002),0.00003 $\mu \mathrm{g} / \mu \mathrm{L}$ and $0.0002 \mu \mathrm{g} / \mu \mathrm{L}$, respectively show that all PAHs congener are within the MCL set by EC and USEPA. 50\% of the samples was not detectable with PAHs. The absence of PAHs congeners in the some of the samples may be as a result of the method of preparation .Processing (drying ,smoking) and cooking of food at high temperature (drying, frying, roasting, bakery) are commonly considered to the major source of food contamination by PAHs (Fretheim,1983).None of these methods are applied in the production of soft drinks.

Benzo(a)pyrene which was used as the benchmark for carcinogenicity to other PAHs, due to its ability to have strong carcinogenic effect on laboratory animals and man(Adebayo et al.,2012) was not detected in this study(Table 5), and thus, pose no potential health risk to the populace exposed to the soft drink. In this current study, the carcinogenic and non-carcinogenic risk of PAHs were not calculated because they occurred in relatively low amount. Some PAHs can affect health when exposure is at levels higher than the maximum concentration limit (MCL) for relatively short period of time. The damage include suppressed immune systems, or red blood cell damage leading to anaemia (Abiodun et al.,2017).PAHs are toxic and their carcinogenicity is limited by their metabolic conversion to peroxides that bind covalently to cellular macromolecules, including DNA, causing an increase of elevated levels of DNA adducts and developing errors in DNA replication which causes carcinogenesis in both human and other organisms (Kumar et al.,2014).

\section{Conclusion}

Although soft drinks are consumed due to their numerous benefits, they can also be a potential source of toxic metals. This contamination may due to contamination of ingredients, surface water and groundwater used during production and also reported by manufacturers during the beverage processing and packaging and storage stages (Pofahl et al., 2005).From the results observed in this study the levels of $\mathrm{Hg}$ were within the permissible limit set by WHO, USEPA and SON. Pb levels exceed the maximum limit set by regulatory bodies. $\mathrm{Cd}$ and as levels in 19\% and 50\% respectively, in the soft drink samples were above the recommended limit. The carcinogenic risk was higher in $\mathrm{Cd}$ and lowest in $\mathrm{Pb}$. In addition, the estimated daily intake for $\mathrm{Hg}$ were within the reference dose, thus, poses no health risk. The THQ for heavy metals in this study were greater than unity. Except Hg which has its THQ below unity .The hazard indices due to combined non-cancer effects of all the metals considered in this study were $>1$.The PAHs congeners were absent in 50\% of the soft drink samples. In addition, Benzo(a)pyrene, which was considered as the most carcinogenic pollutant is not detected in this present study. Consumption of the soft drink samples pose potential health risk with respect to Cd and As.

\section{References}

[1] Abiodun O. A, Omobola O. O and Anthony I. O (2017). Analytical methods for polycyclic Aromatic Hydrocarbons and their Global Trend of Distribution in water and sediment: A Review.Intechnopen.J. 
[2] Adebayo,C.O and Sanni,S.A and Baiyegunhi,J.S(2012).Microcredit scheme impact and food security status of status of beneficiaries in Kaduna State,Nigeria:A propensity score matching approach.African journal of Agricultural Research Vol.7(37).pp5191-5197. https://doi.org/10.5897/AJAR12.475.

[3] Adegbola R.A,Adekanmbi A.I,Abiona D.L,Atare A.A.,(2015).Evaluation of some HM Contaminants in biscuits,fruit drinks,Concentrates,candy,milk products and carbonated drinks sold in Ibadan,Nigeria.Int.J.Brain Cognit.sci.9,1611-1696. https://doi.org/10.4314/ijbcs.v9i3.47.

[4] Adepoju-Bellow A.A., Oguntibeju,O.O ,Onuebu,M.T,Ayoola,G.A and Coker,H.A.B (2012).Analysis of Selected Metallic Impurities in soft drinks marketed in Lagos,Nigeria.African Journal of Biotecnology vol 11(20).pp4676-4680,Available online.http://www.academic journals.org(A)(B). https://doi.org/10.5897/AJB11.3961.

[5] Ahmadi A and Ziarati P, (2015). Chemical Composition Profile of canned and frozen sweet corn (Zea mays) in Iran.Orient.J.Chem.31.1065-1070. https://doi.org/10.13005/ojc/310256.

[6] Akan J,Kolo B,Yikala B and Ogugbuaja M.(2013).Determination of some HMs in vegetable Samples from Biu local gov area,Borno State,North Eastern Nig.Int.J.Environmental Anal.1,40-46 https://doi.org/10.11648/j.ijema.20130102.11.

[7] Alani,R.Olayinka,K.and Alo,B(2013).Studies on persistent organic pollutants(POPs) in the Lagos: Occurrence and levels of polycyclic aromatic hydrocarbons (PAHs) in engeering and applied sciences (JETEAS),4(6),2013,811-818.

[8] Al-Mudhaf H,Alzaid H, and Abu-Shady A I.(2016).Study of trace and heavy metals Content of soft drinks in the state of Kuwait.Int.J.Eng.Res.App.6(5),1.

[9] Arigbede,O.E Olutona,G.O and Dawodu,M.O(2019)Dietary Intake and Risk Assessment of heavy metals from selected Biscuit Brands in Nigeria.J Heavy Met Toxicity Dis Vol.4 No.2:3.

[10] Ashraf W, Jaffa M., and Masud K (2000). Heavy trace metal and macronutrient levels in various soft drinks and juices.Journal of the chemical society of pakistan.22:119-124.

[11] Bingol M., Yentur,Er B., and Oktem A,B(2010).Determination of Some heavy metal levels in soft drinks from Turkey using ICP/OES method.Czech J.Food Sci.,28:213-216 https://doi.org/10.17221/158/2008-CJFS.

[12] Brazkova M, and Krastanov A. (2013). Polycylic aromatic hydrocarbons sources,effects and biodegredation.Proceedings of the international scientific conference of university of Ruse,Razgard,Bulgaria.52(102):1-5.

[13] Dehelean A and MagdasbD.A(2013). Analysis of mineral and heavy metal content of some Commercial fruit juices by inductively coupled plasma mass spectrometry. Sw world J.2013 https://doi.org/10.1155/2013/215423.

[14] European Communities (EC) (1998), The quality of water intended for human consumption,official journal of the European communities.Council Directives 98183/EC. http//.www.fsai.ie/uploadedfiles//Legislation(food)Lagislation_Links/water/EU_Directive_98_83_EC.pdf.

[15] Fang Y,Zhang A,Wang H,LI H,Zhang Z,Chen S and Luan L.J.F.C.(2010).Health risk assessment of trace elements in Chinese raisins produced in Xinjiang province.Food Control 21(5),732-739 https://doi.org/10.1016/j.foodcont.2009.10.018.

[16] Fathabad A.E,Shariatifar N,Moazzen M,Nazmara S,Fakhri Y,Alimohammed M,Azari A, and khaneghah A.M.J.F.(2018).Determination of heavy metal content of processed fruit products from Tehrans market using ICP-OES:a risk assessment study https://doi.org/10.1016/j.fct.2018.03.044

[17] Fu J,Zhou Q,Liu J,Liu W,Wang T,Zhang Q and Jiang G.J.C.(2008).High levels of heavy metals in rice (Oryza sativa L.)from a typical E-waste recycling area in southeast China and its potential risk to human health.Chemoshere .71,(7),1269-1275 https://doi.org/10.1016/j.chemosphere.2007.11.065.

[18] FEPA (1991). Federal Environmental Protection Agency Guidelines and Standards for Environmental pollution control in Nigeria. p35.

[19] Fretheim K (1983). Polycyclic Aromatic Hydrocarbon in Grilled meat products-A review.Food chemistry vol 31.p1083-1090.[Pubmed][Google Scholar]. https://doi.org/10.1016/0308-8146(83)90029-8.

[20] Godwill E.A,Jane I.C, Scholastica I.U,Marcellus U,Eugene A.L, and Gloria O.A(2015).Determination of some soft drinks constituents and contamination by some heavy metals in Nigeria.Toxicology Reports ,2,384-390 https://doi.org/10.1016/j.toxrep.2015.01.014.

[21] Hague T, Petroczi A,Andrew P.L,Barkery and Naughton D.P(2008).Determination of Metal ion content of beverages and estimation of target hazard quotients:a comparative study.Chem Cent J,2:13 https://doi.org/10.1186/1752-153X-2-13.

[22] Harnack L,Stang J and Story M.(1999).Soft drink consumption among US children and adolescents:nutrional consequences.Journal of American Dietetic Association 99(4),436-441. https://doi.org/10.1016/S0002-8223(99)00106-6.

[23] Halek.F,Nabi.G.H,Ganjidoust.H,Keyanpour.M, and Mirmohammadi.M.(2006).Particulate polycyclic aromatic hydrocarbons in urban air of Tehran,Iran J.Environ.Health Sci.Eng.,3(3),247-254.

[24] Jarup L (2003). Hazards of Heavy metal Contamination. British medical Bulletin.68:419 https://doi.org/10.1093/bmb/ldg032.

[25] Krejpcio Z., Stonkowski,S and Bartela,J(2005).Safety of Fresh Fruits and Juices available on the Polish market as determined by heavy metal residues, Polish Journal of Environmental studies, 14:877-879.

[26] Kumar B,Tyagi ,Verma VK,Gaur R and Sharma C,S(2014).Concentration,Sources,Idntification and health risk of selected Priority Polycyclic aromatic hydrocarbons in resential street soils .Advanced Applied Science Research.5(3):130-131.

[27] Liu X,Song Q,Tang Y,Li w,Xu J,et al.,(2013).Human healt risk assessment of heavy metals in soil-vegetable system:a multi-medium analysis.Sci Total Environ 463:530-540. https://doi.org/10.1016/j.scitotenv.2013.06.064.

[28] Lorenzo.D,Entwistle.J.A,Cave.M, and Dean.J.R.(2011).Determination of polycyclic aromatic hydrocarbons in urban street dust:implications for human health,Chemosphere,83(7),970-977. https://doi.org/10.1016/j.chemosphere.2011.02.020.

[29] Magomaya A.M., Yebpella G, G and Okpaegbe U.C (2015). An Assessment of metal Contaminant levels in selected soft drinks sold in Nigeria.Intl of Innovative Science,Engineering \& Toxicology vol 2.

[30] Maliszewska-Kordybach.B,Smreczak,B and Klimkowicz-Pawlas.A.(2009).Concentrations,source and spatial distribution of individual polycyclic aromatic hydrocarbons (PAHs) in agricultural soils in the Eastern part of the EU:Poland as a case study.Sci.Total Environ,407(12),3746-3753. https://doi.org/10.1016/j.scitotenv.2009.01.010.

[31] Maduabuchi J.M.U.,Nzegwu C.N.,Adigba E,O.,Aloke R.U.,Ezomike C.N.,Okocha C,E.,Obi E., and Orisakwe O.E(2006).Lead and Cadmium exposures from canned and non-canned beverages in Nigeria.A Public health concern.Science Total of Environment .366:621-626 https://doi.org/10.1016/j.scitotenv.2005.12.015.

[32] Martorell I,Perello G,Marti-Cid.R,Castell.V,Liobet.J.M and Domingo.J.L(2010).Polycyclic aromatic hydrocarbons(PAHs) in food and estimated PAH intake by the population of Catalonia,Spain:temperoral trend.Environ Int.J.,36(5),424-432. https://doi.org/10.1016/j.envint.2010.03.003.

[33] Mathur H, P, Johnson S and Kumar A. (2003)." Analysis of pesticide residue in soft drinks "Centre for Science Env (CSE) Report, India.

[34] Michna,W and Szteke,B(2001).Report of monitoring of quality of soils,plants and agricultural and food products in the year 2000.Ministry of Agriculture and Rural Development,(eds),Warszawa,pp23-113,(in polish).

[35] Nabi, S.Fatemeh,S.Behnoz,J.Shahrokh,N and Majid,A.(2020).The concentration and health risk assessment of trace elements in commercial soft drinks from Iran marketed.Intl J.of Environmental Analytical chemistry.

[36] Nagajyoti,P.C,Lee,K.D, and Sreeknanth,T.V.M.(2010)Heavy metals,occurrence and toxicity for plants: a review.Environmental Chemistry Letters,vol. 8,no 3,pp.199-216. https://doi.org/10.1007/s10311-010-0297-8.

[37] Ofori H., Owusu,M and Anyebuno,G(2013).Heavy Metal Analysis of Fruit Juice and Soft drinks bought from retail market in Accra,Ghana,Journal of Scientific Research and Reports 2(1)pp423-428. https://doi.org/10.9734/JSRR/2013/3377.

[38] Ogunlana O.O,Ogunlana O.E,Akinsanya A.E and Ologbenla O.O(2015).Heavy metal analysis of selected soft drinks in Nigeria .Journal of Global Biosciences.4(2)pp1335-1338.

[39] Orisakwe O,E.,Oragwu C.I.,Maduabuchi,J.M.U.,Nzgwu C.N and Nduka J.K.C.,(2009).Copper,Selenium and Zinc content of canned and noncanned beverages in Nigeria ,African Journal of Environmental Science and Technology,3(1),pp042-049. 
[40] Perra.G,Pozo.K,Guerranti.C,Lazzeri.D,Volpi.V,Corsolini.S and Forcardi.S.(2011).Levels and spatial distribution of polycyclic hydrocarbons(PAHs) in superficial sediment from 15 Italian marine protected area (MPA).Mar Pollut Bull,62(4),874-877 https://doi.org/10.1016/j.marpolbul.2011.01.023.

[41] Pofahl G.M,Capps and Clauson A.l(2005).Demand for Non-Alcoholic Beverage: Evidence from the ACNielsen Home Scan Panel.Selected paper at the American Agricultural Economics Association Annual Meeting, Providence, RI July 24-27,2005.

[42] Prycek.J,Ciganek.M, and Srinek.Z.(2007).Clean-up of extracts for nitrated derivatives of polycyclic aromatic hydrocarbons analysis prior their gas chromatography dtermination"Journal Brazilian Chemical Society ,18,1125-1131. https://doi.org/10.1590/S0103-50532007000600004

[43] Roberts I. I and Orisakwe O. E (2011). Evaluation of potential dietary toxicity of heavy metals in some common Nigeria beverages:A look at antimony,tin and mercury.Qscience Connect,2. https://doi.org/10.5339/connect.2011.2.

[44] Salma I,Sajib M,Motalab M,Muntaz B,Jahan S,Hoque,M and Saha B.(2015).Comparative evaluation of macro and micro-nutrient element and heavy metal contents of commercial fruit juices available in Banladesh.Am.J.food,Nutr.3,56-63.

[45] Scientific Committee on foods of EC(SCF)(2002), the opinion of the scientific committee on food on the risk to human Health of PAHs in food.SCF/CS/CNTM/PAH/29 final European Commission,Health and Consumer Protection Directorate-General ,Brussels.

[46] Sharma R,K.,Singh A, Agrawal,A and Marshall F,M(2010).’'Risk assessment of heavy metal toxicity through Contaminated vegetables from waste water irrigated area of varanasi ,India”Tropical Ecology,vol 51.no 2.pp375-387.

[47] Simko P (2002). Determination of Polycyclic aromatic hydrocarbons in smoked meat products and smoke flavouring food additives.J. Chromatogr.B770(1-2) (3-18). https://doi.org/10.1016/S0378-4347(01)00438-8.

[48] SON (2002). Nigeria Standards for Drinking water quality, Revised edition 2007.

[49] Tang W, Duan S, and Shan,B et al.,(2006).Concentrations diffusive Fluxes and toxicity of heavy metals in pore water of the Fuyang River,Haihe Basin ,"Ecotoxicology and Environmental safety,vol.127pp.80-86. https://doi.org/10.1016/j.ecoenv.2016.01.013.

[50] Ubong I,u.,Obunwo C and Faafa A.,(2016).Essential and Non-Essential metals in soft drink drinks consumed and sold in Port Harcourt,Nigeria RA Journal of Applied Research vol2(08)pp550-557.Issue:2394-6709.

[51] US Environmental Protection Agency (USEPA) (1993). Provisional Guidance for Quantitative Risk Assessment of Polycyclic Aromatic Hydrocarbons EPA/600/R-93/089, U.S Environmental Protection Agency,Washington,D.C:Office of Research and Development.

[52] United States Environmental Protection Agency (USEPA) (2012). Drinking Water Standard and Health Advisories,12:3-4.

[53] USEPA (2002). Polycyclic organic matter.Environmental Protection Agency, Washington ,Dc. Available at http://www.epa.gov/ttn/atw/html/polycyclic.html.

[54] Vaux,B and Golder,s.(2003)."105.what is your generic term for sweetened carbonated beverage?".

[55] WHO (2006). World Health Organisation Guidelines for drinking water quality, Recommendation Geneva, Switzerland.

[56] Zhong, W., and Wang, M (2002). Some polycyclic aromatic hydrocarbons in vegetables from northern China. J. Environ. Sci. Health A37:287-296. https://doi.org/10.1081/ESE-120002588. 